\title{
Front Matter: Volume 10673
}

, "Front Matter: Volume 10673," Proc. SPIE 10673, Advances in Ultrafast

Condensed Phase Physics, 1067301 (31 July 2018); doi: 10.1117/12.2502124

SPIE. Event: SPIE Photonics Europe, 2018, Strasbourg, France 


\title{
PROCEEDINGS OF SPIE
}

\section{Advances in Ultrafast Condensed Phase Physics}

\author{
Martin Schultze \\ Eleftherios Goulielmakis \\ Thomas Brabec \\ Editors
}

23-24 April 2018

Strasbourg, France

Sponsored by

SPIE

Cosponsored by

Strasbourg the Europtimist (France)

CNRS (France)

Investissements d'Avenvir (France)

iCube (France)

Université de Strasbourg (France)

Cooperating Organisations

Photonics 21 (Germany)

EOS-European Optical Society (Germany)

Photonics Public Private Partnership (Belgium)

Comité National d'Optique et de Photonique (France)

Published by

SPIE

Volume 10673 
The papers in this volume were part of the technical conference cited on the cover and title page. Papers were selected and subject to review by the editors and conference program committee. Some conference presentations may not be available for publication. Additional papers and presentation recordings may be available online in the SPIE Digital Library at SPIEDigitalLibrary.org.

The papers reflect the work and thoughts of the authors and are published herein as submitted. The publisher is not responsible for the validity of the information or for any outcomes resulting from reliance thereon.

Please use the following format to cite material from these proceedings:

Author(s), "Title of Paper," in Advances in Ultrafast Condensed Phase Physics, edited by Martin Schultze, Eleftherios Goulielmakis, Thomas Brabec, Proceedings of SPIE Vol. 10673 (SPIE, Bellingham, WA, 2018) Seven-digit Article CID Number.

ISSN: 0277-786X

ISSN: 1996-756X (electronic)

ISBN: 9781510618725

ISBN: 9781510618732 (electronic)

Published by

SPIE

P.O. Box 10, Bellingham, Washington 98227-0010 USA

Telephone +1 3606763290 (Pacific Time) · Fax +1 3606471445

SPIE.org

Copyright $(2018$, Society of Photo-Optical Instrumentation Engineers.

Copying of material in this book for internal or personal use, or for the internal or personal use of specific clients, beyond the fair use provisions granted by the U.S. Copyright Law is authorized by SPIE subject to payment of copying fees. The Transactional Reporting Service base fee for this volume is $\$ 18.00$ per article (or portion thereof), which should be paid directly to the Copyright Clearance Center (CCC), 222 Rosewood Drive, Danvers, MA 01923. Payment may also be made electronically through CCC Online at copyright.com. Other copying for republication, resale, advertising or promotion, or any form of systematic or multiple reproduction of any material in this book is prohibited except with permission in writing from the publisher. The CCC fee code is 0277$786 \mathrm{X} / 18 / \$ 18.00$.

Printed in the United States of America.

Publication of record for individual papers is online in the SPIE Digital Library.

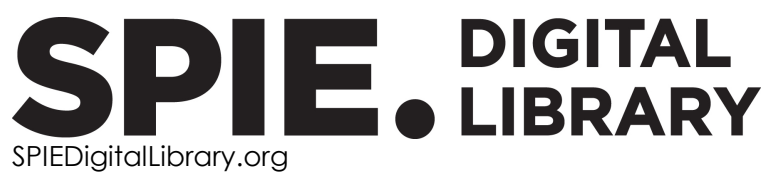

Paper Numbering: Proceedings of SPIE follow an e-First publication model. A unique citation identifier (CID) number is assigned to each article at the time of publication. Utilization of CIDs allows articles to be fully citable as soon as they are published online, and connects the same identifier to all online and print versions of the publication. SPIE uses a seven-digit CID article numbering system structured as follows:

- The first five digits correspond to the SPIE volume number.

- The last two digits indicate publication order within the volume using a Base 36 numbering system employing both numerals and letters. These two-number sets start with 00, 01, 02, 03, 04, 05, 06, 07, 08, 09, OA, OB ... 0Z, followed by 10-1Z, 20-2Z, etc. The CID Number appears on each page of the manuscript. 


\title{
Contents
}

\author{
$\checkmark \quad$ Authors \\ vii Conference Committee
}

ULTRAFAST EXCITATION DYNAMICS I

1067304 Optically excited structural transition in atomic wires on surfaces at the quantum limit: a femtosecond ultrafast surface electron diffraction study (Invited Paper) [10673-4]

$1067306 \quad$ Ultrafast charge cooling and carrier multiplication in semiconductor nanocrystals and superlattices [10673-6]

1067307 Effect of size confinement in C exciton dynamics of few-layered MoS2 nano-sheets [10673-7]

ULTRAFAST EXCITATION DYNAMICS III

10673 OP Attosecond electron pulse trains and applications to time-resolved diffraction and microscopy (Invited Paper) [10673-26] 
Proc. of SPIE Vol. 10673 1067301-4

Downloaded From: https://www.spiedigitallibrary.org/conference-proceedings-of-spie on 26 Apr 2023 Terms of Use: https://www.spiedigitallibrary.org/terms-of-use 


\section{Authors}

Numbers in the index correspond to the last two digits of the seven-digit citation identifier (CID) article numbering system used in Proceedings of SPIE. The first five digits reflect the volume number. Base 36 numbering is employed for the last two digits and indicates the order of articles within the volume. Numbers start with 00, 01, 02, 03, 04, 05, 06, 07, 08, 09, 0A, 0B...0Z, followed by 10-12, 20-2Z, etc.

Baum, Peter, OP

Bhattacharya, Sayantan, 07

Chowdhury, Rup Kumar, 07

Datta, Prasanta Kumar, 07

Horn von Hoegen, Michael, 04

Karmakar, Manobina, 07

Kulkarni, Aditya, 06

Morimoto, Yuya, OP

Mukherjee, Subhrajit, 07

Ray, Samit K., 07

Siebbeles, Laurens D. A., 06 
Proc. of SPIE Vol. 10673 1067301-6

Downloaded From: https://www.spiedigitallibrary.org/conference-proceedings-of-spie on 26 Apr 2023 Terms of Use: https://www.spiedigitallibrary.org/terms-of-use 


\title{
Conference Committee
}

\author{
Symposium Chairs
}

Francis Berghmans, Vrijie Universteit Brussel (Belgium)

Thierry Georges, Oxxius SA (France)

Harald Giessen, Universität Stuttgart (Germany)

Paul Montgomery, Université de Strasbourg (France)

Conference Chairs

Martin Schultze, Max-Planck-Institut für Quantenoptik (Germany)

Eleftherios Goulielmakis, Max-Planck-Institut für Quantenoptik (Germany)

Thomas Brabec, University of Ottawa (Canada)

Conference Programme Committee

Dimitrios Charalambidis, Foundation for Research and TechnologyHellas (Greece)

Peter Hommelhoff, Max-Planck-Institut für Quantenoptik (Germany)

Gerhard G. Paulus, Helmholtz Institute Jena (Germany)

Klaus Reimann, Max-Born-Institut für Nichtlineare Optik und Kurzzeitspektroskopie (Germany)

Olga Smirnova, Max-Born-Institut für Nichtlineare Optik und Kurzzeitspektroskopie (Germany)

Vladislav Yakovlev, Max-Planck-Institut für Quantenoptik (Germany)

\section{Session Chairs}

1 Novel Tools for Ultrafast Spectroscopy

Martin Schultze, Max-Planck-Institut für Quantenoptik (Germany)

2 Ultrafast Excitation Dynamics I

Eleftherios Goulielmakis, Max-Planck-Institut für Quantenoptik (Germany)

3 Ultrafast Excitation Dynamics II

Martin Aeschlimann, Technische Universität Kaiserslautern (Germany)

4 Electron Dynamics in Nanosystems

Markus Münzenberg, Universität Greifswald (Germany) 
5 High Harmonic Generation, Attosecond Physics in Solids

Eleftherios Goulielmakis, Max-Planck-Institut für Quantenoptik (Germany)

Vladislav S. Yakovlev, Max-Planck-Institut für Quantenoptik (Germany)

6 Ultrafast Excitation Dynamics III

Eleftherios Goulielmakis, Max-Planck-Institut für Quantenoptik (Germany) 